\title{
Evaluation of Microorganisms of Drinking Water of Rafha City, Northern Borders, Saudi Arabia
}

\section{Abdel Haleem AA ${ }^{1,2 *}$, Hemida $S^{1,3}$ and Abdellatif $\mathbf{M M}^{1,4}$}

${ }^{1}$ Department of Biology, Faculty of Arts \& Science, Northern Border University, Rafha, Saudi Arabia

${ }^{2}$ Biological Department, Faculty of Education, Ain Shams University, Cairo, Egypt

${ }^{3}$ Botany Department, Faculty of Science, Assiut University, Egypt

${ }^{4}$ Department of Zoology, College of Veterinary Medicine, Nyala University, Sudan

\begin{abstract}
The present studies included evaluation of pathogenic parasitic protozoans, bacteria, fungi and algae collected from drinking water of three sources; wells, tap and three re-purifying water-private companies; from Rafha City, Northern Borders, Saudi Arabia, to count and identify these contaminants. The results revealed three species of parasitic protozoans (Giardia lamblia, Cryptosporidium parvum and Cyclospora cayetanensis), Four species of Coliform bacteria (Proteus mirabilis, Escherichia coli, Enterobacter cloacae and E. aerogenes) beside seven bacterial genera (Bacillus, Brevibacillus, Staphylococcus, Streptococcus, Aeromonas, Acinetobacter and Pseudomonas), five genera of fungi (Aspergillus, Chrysoporium, Alternaria, Acremonium and Exophiala) as well as three genera of algae in tap and the present three re-purifying water-private companies (Anabaena, Microcystis and Oscillatoria). The present results indicated that the three water sources of Rafha city are important contributor to transmission of contaminants to consumers. The present work recommends future field-application of selected specialized antiparasites and anti-bacterial compounds to control, or at least reduce the present resulting contaminators to gain safe levels of drinking water, according to WHO (World Health Organisation -, or at least SASO (Saudi Standards, Metrology and Quality Organization) - levels, to reduce the risk of propagation of the present microorganisms.
\end{abstract}

Keywords: Drinking water contaminants; Protozoa; Bacteria; Fungi; Algae

\section{Introduction}

Water is scarce and valuable resource in Saudi Arabia. Thereby, well or ground water is still and will continue to be one of the main sources of drinking water in Saudi Arabia, especially in rural and border areas. The microbial contamination of drinking water constitutes a major issue worldwide, because it is still a major source of infection and mortality. Evaluation of the microbiological quality of drinking water aims to protect consumers from illness, that due to protozoon's parasites, bacteria, fungi, algae and viruses. Nowadays, prevention of contaminated drinking-water-related-illness is still an important challenge [1]. Rafha-citizens basically obtained their drinking water from treated wells stored in public tanks and re-distributed through waterborne-pipes to houses. However, citizens are usually avoid using tap water as a source of drinking water, owing to their dis-satisfaction of taste, odour and colour of this water. Instead, they prefer drinking water-consumption of desalinated groundwater obtained from some desalinating-private companies others drink industrially bottled water. The famous protozoan parasites contaminating drinking water are Giardia, Cryptosporidium, Entamoeba histolytica and Cyclospora, that cause severe gastrointestinal disorders; namely giardiasis, cryptosporidiosis, amoebiasis and cyclosporiasis respectively [2]. Indication of the presence of disease-causing bacteria in drinking water is the coliform bacteria, that are non-pathogenic but associated with many diseases; from which Proteus, Escherichia coli and Enterobacter; indicating faecal contamination of water. Proteus mirabilis is associated with urinary tract infections [3].

In this concept, the coliforms constitute common intestinal commensal bacteria. This group contains important pathogens, as E. coli, which is the most prominent and causes disease when the immune-system is suppressed [4]. E. coli considered as an indicator of fecal contamination when found in drinking water [5]. Enterobacter species act as opportunistic pathogens.
Many other bacteria are pathogenic, such as Streptococcus that colonizes the heart valves [6], Aeromonas that produces cytotoxicenterotoxin causes tissue damage [7], Acinetobacter that causes urinary tract infections, pneumonia, endocarditis, wound infections, septicemia and meningitis [8] as well as Pseudomonas that causesbronchopneumonia, ecthyma gangrenosum, urinary tract catheterization, necrotising enterocolitis, hemorrhage, necrosis of the skin [9].

On the other hand, some fungi are pathogenic; such as Aspergillus that causes chronic pulmonary aspergillosis [10], Chrysoporium that cause hyalo-hyphomycosis [11], Alternaria that cause respiratory infections [12] and Acremonium that cause mycetoma, onychomycosis, and hyalohyphomycosis [13].

Some algal genera are pathogenic, as; Anabaena, Microcystis and Oscillatoria. These genera secrete toxins, as Anabaena and Microcystis that secrete microcystin-LR and cylindrospermopsin, leading to liver inflammation, pneumonia, dermatitis, kidney damage and tumor growth and anatoxin-a group-toxin from Anabaena and Oscillatoria that causes nervous disorders [14].

SASO (Saudi Arabian Standards Organization) continuously evaluates drinking water standards for bottled, tap and well-waters to define a quality of water that re-inforce healthy population. These standards set limits for the permissible and maximum contaminants

*Corresponding author: Department of Biology, Faculty of Arts \& Science Northern Border University, Rafha, Saudi Arabia, Tel: 966508379140; E-mail abdelsalam1958@windowslive.com

Received December 29, 2016; Accepted June 15, 2016; Published June 20, 2016.

Citation: Abdel Haleem AA, Hemida SK, Abdellatif MM (2016) Evaluation of Microorganisms of Drinking Water of Rafha City, Northern Borders, Saudi Arabia. J Cytol Histol 7: 417. doi:10.4172/2157-7099.1000417

Copyright: (c) 2016 Abdel Haleem AA, et al. This is an open-access article distributed under the terms of the Creative Commons Attribution License, which permits unrestricted use, distribution, and reproduction in any medium, provided the original author and source are credited. 
level of parasites and the indicator-microorganism that endanger the health of consumers [15]. A substantial number of these standards are originated from the accurate World Health Organization internationalstandards for drinking water [16]. The main objective of this study is to assess the parasitological and microbiological status of drinkable water of Rafha City in Saudi Arabia.

\section{Materials and Methods}

\section{Water sampling}

The present studies were carried out from July to October, 2014, in Rafha City, Northern Borders, Saudi Arabia. The water-samples had been collected from three major water sources; ten wells, tap and three private desalinating companies; El-Shefaa, Bardy and El-Razaz. Aliquots of $100 \mathrm{ml}$ from each water-sample were collected in sterilized conical flasks, provided with silica gel to keep dryness.

\section{Enumeration of protozoans, bacteria, fungi and algae}

Protozoan parasites: All samples preserved in $4 \%$ neutralized formalin solution, left to settle [17]. Then, supernatants were collected, filtered through $20 \mu \mathrm{m}$ net mesh. Materials that retained by filter were then fixed with Lugol's solution. The protozoans were then counted by Sedwgwish Rafter counting method and identified (Cells/100 ml), using Olympus binocular compound microscope.

To confirm identification of Giardia lamblia and Cryptosporidium parvum, aliquots of $100 \mathrm{ml}$ of water samples were filtered through a $47 \mathrm{~mm}$ diameter, $0.450 \mu \mathrm{m}$ pore size membrane filter. Each material retained by the filter was fixed with Lugol iodine on a separate slide. Fresh preparations of $0.9 \%$ saline smear of samples were visually examined for parasitic cysts over approximately 100 fields and then subjected to cold acid-fast. Trichrome staining technique was then applied [18].

\section{Bacteria-count}

Coliform bacteria: Coliform bacteria were determined by incubation of samples into lactose broth as presumptive test. The test tubes are placed at $35^{\circ} \mathrm{C}$ for 24 hours for gas production. To confirm the presence of coliform, gas produced in incubation into Brilliant Green Bile broth at $35^{\circ} \mathrm{C}$ for 24 hours [19]. Water quality analysis was based on the most probable number of Cells $/ 100 \mathrm{ml}$. The test had been repeated three times.

Aerobic and other facultative anaerobic bacteria: One $\mathrm{ml}$ of each water sample was inoculated and spread on blood agar and nutrient agar plates. Then, plates were incubated at $37^{\circ} \mathrm{C}$ for 18 to $24 \mathrm{~h}$ for determination of bacterial cell count, as cells $/ 100 \mathrm{~mL}$, and for isolation and differentiation of various bacterial strains depending on their morphological descriptions. Different isolated bacteria were further identified by Bilog system (Biolog, Hayward, CA, USA). Experiment had been repeated three times [20].

Fungi: Sabouraud Dextrose Agar (SDA) was used as a culture medium to reveal the presence of fungi and chloramphenicol is used to increase selectivity against commensal microorganisms. For isolation of fungi from water-contaminated specimens, SDA-medium should be inoculated and the plates incubated at $28^{\circ} \mathrm{C}$ in an inverted position with increased humidity. For isolation of fungi, two sets of media should be inoculated at $28^{\circ} \mathrm{C}$ and a duplicate set at $35^{\circ} \mathrm{C}$. All cultures should be examined 7-10 days for fungal growth, and should be held for 5 weeks before being reported as negative [21]. The test had been repeated three times.
Algae: Aliquots of $100 \mathrm{ml}$ from each water sample were allowed to settle overnight in sterilized conical flasks. Then after, solid materials from the bottom of the flasks were pipetted for examination. The experiment had been repeated thrice. Algal species had been identified using binocular microscope (Zeiss) [22].

\section{Statistical Methods}

Analysis of Variance "ANOVA": The mean data of analysis of variance "ANOVA", between four categories, protozoans, bacteria, fungi and algae to obtain significant differences, using the statistical SPSS-program.

\section{Results}

\section{Protozoan parasites}

The present result showed four protozoan-species, as cysts, Giardia lamblia (Diplomonadida, Hexamitidae), Cryptosporidium parvum (Eucoccidiorida, Cryptosporidiidae), Cyclospora cayatenensis (Eucoccidiorida, Eimeriidae) and Entamoeba coli (Archamoebae) (Table 1).

Table 1 display average counts the highest values in water of the different wells $(5.8,21,0.7$ and 15.1 cells/100 $\mathrm{ml}$ for G. lamblia, C. parvum, C. ayetanensis and E. coli respectively) whereas $C$. cayetanensis revealed the highest value in tap water, whereas all species were completely absent in water of the three private companies. On the other hand, frequency \% revealed the highest values; of G. lamblia and E. coli in all sources of water $(28.57,27.27$ and $33.33 \%$ in well-, tap and companies-water respectively), highest values of C. cayetanensis in tap and the three companies-water (27.27 and $33.33 \%$ respectively) and the highest value of $C$. cayetanensis in well-water (28.57\%) (Table 2). The statistical analysis of variance "ANOVA" revealed highly significant differences in the two species G. lamblia and C. parvum.

\section{Bacteria}

Coliform Bacteria: The present work reported four gram-negative coliform bacteria-species; facultative anaerobic Proteus mirabilis, Escherichia coli, Enterobacter cloacae and E. aerogenes.

Table 1 displays mean counted numbers, as CFU/100 ml, where the highest values of $P$. mirabilis, E.cloacae and E. aerogenes had been found in well-water (1318.7, 34.2 and 92.5 respectively), beside the highest value of E. coli in El-Razaz Company-water (700).

On the other hand, frequency\% revealed the highest values; $P$. mirabilis in well-water (22.73\%), P. mirabilis and E. aerogenes in tap water (11.11\%), P. mirabilis in El-Shefaa company (42.86\%), E. cloacae in Bardy company (33.33\%) and E. coli in El-Razaz company (42.86\%) (Table 3).

\section{Aerobic bacteria}

Gram negative bacteria: Beside the previous coliform bacteria; aggregated gram negative Acinetobacter haemolyticus and coccobacillus gram-negative Pseudomonas aeruginosa resulted.

The mean counts, as CFU/100 ml, displays the highest values of A. haemolyticus and P. aeruginosa in well-water (16.7 and 100000 respectively).

The frequency\% revealed the highest values; $P$. aeruginosa in wells (11.36\%) and A. haemolyticus in Bardy company (11.11\%) (Table 4).

Gram positive bacteria: Obligate aerobe Bacillus subtilis, rod 
Citation: Abdel Haleem AA, Hemida SK, Abdellatif MM (2016) Evaluation of Microorganisms of Drinking Water of Rafha City, Northern Borders, Saudi Arabia. J Cytol Histol 7: 417. doi:10.4172/2157-7099.1000417

Page 3 of 7

shaped Brevibacillus brevis and clusters of spherical Staphylococcus hominis resulted. The highest values of mean counts of $B$. subtilis and B. brevis, as CFU/100 ml, detected in wells ( 8.3 and 92.5 respectively) S. hominis in tap water (333.3). The frequency \% scored only B. subtilis and $B$. brevis in well-water ( 2.27 and 6.82 respectively) while $S$. hominis isolated from tap water (11.11).
Anaerobic bacteria: The present results revealed gram positivefacultative species included Bacillus cereus, B. anthracis and Staphylococcus aureus and gram negative-facultative Aeromonas hydrophila and gram-positive-facultative aerobic Streptococcus sanguis. The highest values of mean counts, as CFU/100 ml, detected B. cereus, S. sanguis and A. hydrophila in wells $(11.7,166.7$ and 17.5

\begin{tabular}{|c|c|c|c|c|c|c|}
\hline \multirow[t]{3}{*}{ Species No. } & \multirow[t]{3}{*}{ Total isolated-species } & \multicolumn{5}{|c|}{ Average count $/ 100 \mathrm{ml}$} \\
\hline & & \multirow[b]{2}{*}{ Wells } & \multirow[b]{2}{*}{ Tap water } & \multicolumn{3}{|c|}{ Private companies } \\
\hline & & & & El-Shefaa & Bardy & El-Razaz \\
\hline & I. Protozoan parasites: & & & & & \\
\hline 1 & Giardia lamblia & $\underline{5.8}$ & 3 & 1.3 & 2 & 2.3 \\
\hline 1 & Cryptosporidium parvum & $\underline{21}$ & 17 & 4.3 & 7.7 & 7.3 \\
\hline 1 & Cyclosporacayetanensis & $\underline{0.7}$ & $\underline{0.7}$ & 0 & 0 & 0 \\
\hline \multirow[t]{3}{*}{1} & Entameba coli & $\underline{15.1}$ & 7.3 & 6 & 12 & 10.7 \\
\hline & II. Coliform bacteria-group "Facultative Anaerobes": & & & & & \\
\hline & Proteus mirabilis & & & & & \\
\hline 1 & Escherichia coli & $\underline{1318.7}$ & 33.3 & 35 & 0 & 0 \\
\hline 2 & Enterobacter cloacae & 192.5 & 370 & 33.3 & 66.7 & $\underline{700}$ \\
\hline 3 & E. aerogenes & $\underline{34.2}$ & 0 & 0 & 6.7 & 0 \\
\hline \multirow[t]{3}{*}{4} & III. Total bacteria: & $\underline{92.5}$ & 3.3 & 0 & 36.7 & 0 \\
\hline & a) Aerobic bacteria: & & & & & \\
\hline & Bacillus subtilis & & & & & \\
\hline 1 & Brevibacillusbrevis & $\underline{8.3}$ & 0 & 0 & 0 & 0 \\
\hline 2 & Staphylococcus hominis & $\underline{92.5}$ & 0 & 0 & 0 & 0 \\
\hline 3 & Acinetobacter haemolyticus & 0 & $\underline{333.3}$ & 0 & 0 & 0 \\
\hline \multirow[t]{2}{*}{4} & b) Other facultative anaerobic Bacteria: & $\underline{16.7}$ & 3.3 & 3.3 & 0 & 0 \\
\hline & Bacillus cereus & & & & & \\
\hline 5 & Bacillus anthracis & & & & & \\
\hline 6 & Staphylococcus aureus & $\underline{11.7}$ & 0 & 3.3 & 3.3 & 3.3 \\
\hline 7 & Streptococcus sanguis & 0.8 & 33.3 & 0 & 0 & $\underline{66.7}$ \\
\hline 8 & Aeromonashydrophila & 166.7 & $\underline{333.3}$ & 0 & 0 & 0 \\
\hline 9 & Pseudomonas aeruginosa & $\underline{166.7}$ & 0 & 33.3 & 0 & 0 \\
\hline \multirow[t]{2}{*}{10} & IV. Fungi: & $\underline{17.5}$ & 0 & 0 & 0 & 0 \\
\hline & Aspergillusfumigatus & $\underline{100000}$ & 0.33333 & 0.33333 & 0 & 0 \\
\hline 1 & Aspergillusflavus & & & & & \\
\hline 2 & Chrysoporiumtropicum & $\underline{1.3}$ & 0 & 0 & 0.7 & 0.3 \\
\hline 3 & Alternaria alternate & $\underline{3.3}$ & 3 & $\underline{4}$ & 2.3 & 3.3 \\
\hline 4 & Acremonium sp. & 1.1 & 0 & 0 & 0 & 0 \\
\hline 5 & Penicillium sp. & 0.9 & $\underline{20.3}$ & 1.3 & 1.7 & 0 \\
\hline 6 & Cladosporiumcladosporioides & 1 & $\underline{1.3}$ & 0 & 0 & 0 \\
\hline 7 & Rhodotorulamucilaginosa & 0 & 0 & 0 & 0 & $\underline{4}$ \\
\hline 8 & Exophialajeanselmei & $\underline{0.1}$ & 0 & 0 & 0 & 0 \\
\hline \multirow[t]{2}{*}{9} & V. Algae: & $\underline{0.3}$ & 0 & 0 & 0 & 0 \\
\hline & Diatoms & $\underline{0.7}$ & 0.3 & 0 & 0 & 0 \\
\hline 1 & Cyclotella sp. & & & & & \\
\hline 1 & Synedra sp. & & & & & \\
\hline 2 & Melosira sp. & 0 & $\underline{3}$ & 0 & 0 & 0 \\
\hline 3 & Cymbella sp. & 0 & $\underline{5}$ & 0 & 0 & 0 \\
\hline 4 & Fragilaria sp. & 0 & $\underline{5.3}$ & 0 & 0.3 & 0 \\
\hline 5 & Nitzschia sp. & 0 & $\underline{4.3}$ & 0 & 0 & 0.7 \\
\hline 6 & Merismopediatenuissima & 0 & $\underline{6}$ & 1.3 & 0.3 & 0 \\
\hline 2 & Anabaena sphaerica & 0 & $\underline{0.3}$ & $\underline{0.3}$ & 0 & 0 \\
\hline 3 & Microcystisaeruginosa & 0 & $\underline{10}$ & $\underline{10.7}$ & 0 & 0.7 \\
\hline 4 & Oscillatorialimnetica & 0 & $\underline{0.3}$ & 0 & 0 & 0 \\
\hline \multirow[t]{2}{*}{5} & & 0 & $\underline{0.7}$ & 0 & 0 & 0 \\
\hline & & 0 & 0 & 0 & $\underline{0.7}$ & 0.3 \\
\hline
\end{tabular}

Table 1: Average counted-number of protozoan parasites, bacteria, fungi and algae (mean count/100 ml) which obtained from water-resources of Rafha city, Saudi Arabia. 


\begin{tabular}{|c|c|c|c|}
\hline Types of water & Giardia lamblia & Cryptosporidium parvum & Cyclospora cayatenensis \\
\hline Well water & 28.57 & 14.29 & 28.57 \\
\hline Tap water & 27.27 & 27.27 & 18.18 \\
\hline El-Shefaa Co. & 33.33 & 33.33 & 00.00 \\
\hline Bardy Co. & 33.33 & 33.33 & 00.00 \\
\hline El-Razaz Co. & 33.33 & 33.33 & 33.33 \\
\hline
\end{tabular}

Table 2: Frequency\% of protozoan parasites in different water sources, Rafha city, Northern Borders, Saudi Arabia.

\begin{tabular}{|c|c|c|c|}
\hline \multirow{2}{*}{ Types of water } & \multicolumn{3}{|c|}{ Isolated coliform groups "negative gram" } \\
\cline { 2 - 4 } & Proteus mirabilis & Escherichia coli & Enterobacter cloacae \\
\hline Well water & 22.73 & 13.64 & 09.09 \\
\hline Tap water & 11.11 & 33.33 & 00.00 \\
\hline El-Shefaa Co. & 42.86 & 14.29 & 00.00 \\
\hline Bardy Co. & 00.00 & 22.22 & 33.33 \\
\hline El-Razaz Co. & 00.00 & 42.86 & 00.00 \\
\hline
\end{tabular}

Table 3: Frequency\% of coliform-group bacteria in different water sources, Rafha city, Northern Borders, Saudi Arabia.

\begin{tabular}{|c|c|c|c|c|c|c|}
\hline \multicolumn{7}{|c|}{ Anaerobic bacteria } \\
\hline Types of water & Bacillus cereus & Bacillus anthracis & Staphylococcus aureus & Streptococcus sanguis & Aeromonas hydrophila & $\begin{array}{c}\text { Pseudomonas } \\
\text { aeruginosa }\end{array}$ \\
\hline Well water & 13.64 & 2.27 & 0 & 0 & 6.82 & 11.36 \\
\hline Tap water & 0 & 0 & 33.33 & 0 & 0 & 0 \\
\hline El-Shefaa Co. & 0 & 0 & 0 & 42.86 & 0 & 0 \\
\hline Bardy Co. & 11.11 & 0 & 0 & 0 & 0 & 0 \\
\hline El-Razaz Co. & 14.29 & 42.86 & 0 & 0 & 0 & 0 \\
\hline \multicolumn{7}{|c|}{ Aerobic bacteria } \\
\hline Types of water & Bacillus subtilis & Brevibacillus brevis & Staphylococcus hominis & \multicolumn{3}{|c|}{ Acinetobacter haemolyticus } \\
\hline Well water & 2.27 & 6.82 & 0 & 4.55 & & \\
\hline Tap water & 0 & 0 & 11.11 & 0 & & \\
\hline El-Shefaa Co. & 0 & 0 & 0 & 0 & & \\
\hline Bardy Co. & 0 & 0 & 0 & 11.11 & & \\
\hline El-Razaz Co. & 0 & 0 & 0 & 0 & & \\
\hline
\end{tabular}

Table 4: Frequency\% of aerobic and anaerobic bacteria in different water sources, Rafha city, Northern Borders, Saudi Arabia.

respectively), B. anthracis in El-Razaz company-water (66.7) and $S$. aureus in tap water (333.3). The detected highest values of frequency \%; B. cereus and B. anthracis in El-Razaz company-water (14.29 and 42.86 respectively) whereas $S$. aureus, $S$. sanguis and A. hydrophila isolated from tap water (33.33), El-Shefaa company-water (42.86) and wellwater (6.82). Regarding bacterial counts, as cells/100 ml, the statistical analysis of variance "ANOVA" revealed highly significant differences in the coliform bacteria Proteus mirabilis and Enterobacter cloacae (Tables 5-7).

\section{Fungi}

The present mycoflora that isolated from drinking water of the target three sources are nine genera; Aspergillus fumigatus, Aspergillus flavus, Chrysoporium tropicum, Alternaria alternate, Acremonium sp., Penicillium sp., Cladosporium cladosporioides, Rhodotorula mucilaginosa and Exophiala jeanselmei-yeast.

Table 1 revealed that $8,4,2,3$ and 3 colonies of fungal genera were isolated from the present three water-sources; wells, tap, El-Shefaa, Bardy and El-Razaz company respectively. The highest values of mean counts of fungal genera, as CFU/100 ml, were for Aspergillus flavus (3.3, 4 and 2.3 for wells, El-Shefaa and Bardy companies respectively), Alternaria alternate (20.3 for tap water) and Penicillium (4 for ElRazaz).

It is worthy of mentioning that the fungus A. flavus appeared in all five water-sources followed by A. alternate in four sources. Concerning counts of the fungi, as $\mathrm{CFU} / 100 \mathrm{ml}$, the statistical analysis of variance "ANOVA" revealed low significant differences between the four sources; wells, tap and the three companies concerning Aspergillus fumigatus and Penicillium whereas rest of fungi show non-significant differences (Table 7).

\section{Algae}

Six algal genera had been isolated from four different watersources except wells; Merismopedia tenuissima, Anabaena sphaerica, Microcystis aeruginosa, Oscillatoria limnetica and diatoms, including; Cyclotella sp., Synedra sp., Melosira sp., Fragilaria sp., Cymbella sp. and Nitzschia sp. The highest values of the resulted mean counts of algae, as cells $/ 100 \mathrm{ml}$, included; M. tenuissima from El-Shefaa and Bardy companies-water (10.7 for both), A. sphaerica, and two diatoms Melosira and Fragilaria from tap water (0.3, 5 and 6 respectively). The collected species from El-Razaz company-water included; O. limnetica (0.7), the diatoms Cymbella sp. and Fragilaria sp. from tap water (4.3 and 6 respectively). M. aeruginosa and the diatoms Cyclotella sp., Synedra sp., Melosira sp. and Nitzschia sp. from tap water $(7,3,5,5.3$ and 0.3 respectively) (Table 1 ).

The highest values of frequency \% of algae-samples are; in tap and El-Shefaa and Bardy companies-water for M. tenuissima (1.7, 10, 10.7 and 10.7) and in El-Razaz company-water for Oscillatoria limnetica (0.7) (Table 6). 
Citation: Abdel Haleem AA, Hemida SK, Abdellatif MM (2016) Evaluation of Microorganisms of Drinking Water of Rafha City, Northern Borders, Saudi Arabia. J Cytol Histol 7: 417. doi:10.4172/2157-7099.1000417

Page 5 of 7

\begin{tabular}{|c|c|c|c|c|c|c|c|c|c|}
\hline Types of water & $\begin{array}{c}\text { Aspergill } \\
\text { us fumigatu s }\end{array}$ & $\begin{array}{c}\text { Asperg } \\
\text { illus } \\
\text { flavus }\end{array}$ & $\begin{array}{l}\text { Chrysoporium } \\
\text { tropicum }\end{array}$ & $\begin{array}{l}\text { Alternaria } \\
\text { alternate }\end{array}$ & Acremonium & Penicillium & $\begin{array}{l}\text { Cladosporium } \\
\text { cladosporioides }\end{array}$ & $\begin{array}{l}\text { Rhodotorula } \\
\text { mucilaginosa }\end{array}$ & Phialophora \\
\hline Well water & 38.89 & 22.22 & 16.67 & 05.56 & 05.56 & 00.00 & 05.56 & 03.00 & 00.00 \\
\hline Tap water & 00.00 & 12.50 & 00.00 & 37.50 & 25.00 & 00.00 & 00.00 & 00.00 & 12.50 \\
\hline El-Shefaa Co. & 00.00 & 50.00 & 00.00 & 25.00 & 00.00 & 00.00 & 00.00 & 00.00 & 00.00 \\
\hline Bardy Co. & 25.00 & 50.00 & 00.00 & 25.00 & 00.00 & 00.00 & 00.00 & 00.00 & 00.00 \\
\hline El-Razaz Co. & 20.00 & 40.00 & 00.00 & 00.00 & 00.00 & 40.00 & 00.00 & 00.00 & 00.00 \\
\hline
\end{tabular}

Table 5: Frequency \% of fungi in different water sources, Rafha city, Northern Borders, Saudi Arabia.

\begin{tabular}{|c|c|c|c|c|c|c|c|c|c|c|}
\hline \multirow{2}{*}{ Types of water } & \multirow{2}{*}{$\begin{array}{c}\text { Merismop } \\
\text { edia tenuissima }\end{array}$} & \multirow{2}{*}{$\begin{array}{l}\text { Anabaena } \\
\text { sphaerica }\end{array}$} & \multirow{2}{*}{$\begin{array}{c}\text { Microcystis } \\
\text { aeruginosa }\end{array}$} & \multirow{2}{*}{$\begin{array}{l}\text { Oscillatoria } \\
\text { limnetica }\end{array}$} & \multicolumn{6}{|c|}{ Diatoms } \\
\hline & & & & & Cyclotella & Synedra & Melosira & Cymbella & Fragilaria & Nitzschia \\
\hline Well water & 00.0 & 00.0 & 00.0 & 00.0 & 00.0 & 00.0 & 00.0 & 00.0 & 00.0 & 00.0 \\
\hline Tap water & 10.0 & 00.3 & 00.7 & 00.0 & 03.0 & 05.0 & 05.0 & 04.0 & 06.0 & 00.3 \\
\hline El- Shefaa Co. & 10.7 & 00.0 & 00.0 & 00.0 & 00.0 & 00.0 & 00.0 & 00.0 & 01.3 & 00.3 \\
\hline Bardy Co. & 10.7 & 00.0 & 00.0 & 00.0 & 00.0 & 00.0 & 00.0 & 00.0 & 01.3 & 00.3 \\
\hline El-Razaz Co. & 00.0 & 00.0 & 00.0 & 00.7 & 00.0 & 00.0 & 00.3 & 00.0 & 00.3 & 00.0 \\
\hline
\end{tabular}

Table 6: Frequency \% of algae in different water sources, Rafha city, Northern Borders, Saudi Arabia.

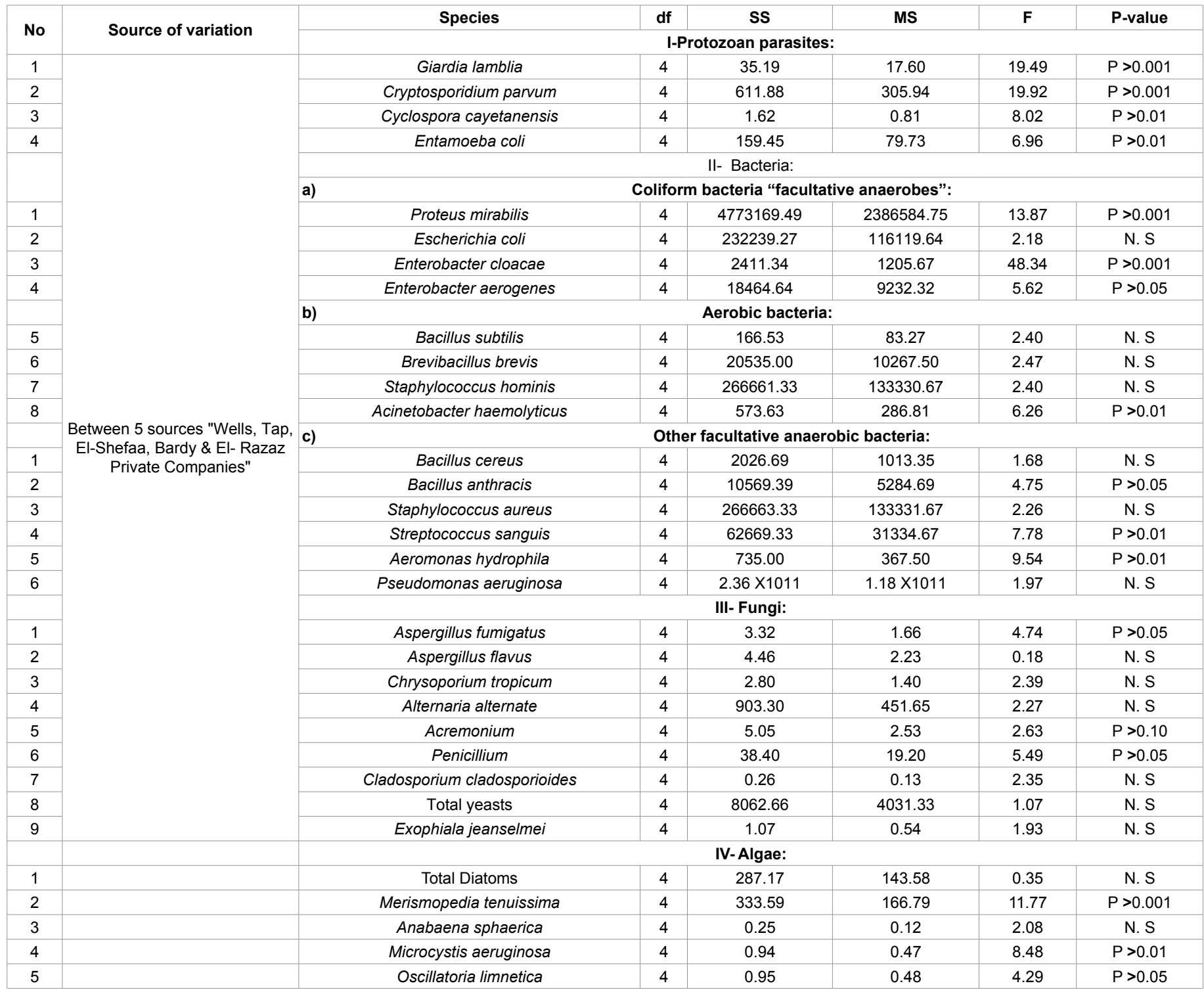

Table 7: Statistical analysis of variance (ANOVA) of counts of protozoan parasites, bacteria, fungi and algae- species (CFU or cells/100 ml water), from different water sources of Rafha City, Saudi Arabia (N.S=non- significant - P>0.001=highly significant). 
Respecting algal counts "cells/100 ml", the statistical analysis of variance revealed highly significant differences in the alga Merismopedia tenuissima between the present four sources (Table 7).

\section{Discussion}

The present work revealed several pathogenic microorganisms in three sources of water; 10 wells, tap and three private desalinating water-companies; including three parasitic protozoan-cysts, three genera of Coliform bacteria-group and some aerobic and anaerobic bacteria, five genera of fungi as well as three genera of algae.

In this respect, results of Al-Turki [23] reinforced the present results where he revealed that microbiological water quality results showed that $20 \%$ of the samples examined are contaminated with coliform bacteria (Escherichia coli, and Enterobacter aerogenes), indicating the necessity of water-sanitation of Hael's water prior to use.

WHO estimated that 1.8 million people die each year as a result of severe diarrhea caused by drinking contaminated water, where developing countries have the prevalence of giardiasis in patients with diarrhea is about $20 \%$ [24].

Concerning parasitic cysts of Giardia lamblia, Cryptosporidium parvum and Cyclospora cayatenensis, they contaminate water-sources causing severe gastrointestinal disorders. The maximum score of the present parasitic protozoans is for C. parvum and minimum count for C. cayetanensis.

Giardia-cysts resist chlorine leads to giardiasis, its symptoms are flu and severe gastrointestinal disorders, detected in $81 \%$ of raw water samples and $17 \%$ of filtered water samples in the United States [25]. In this respect, WHO declared that chlorine disinfection of drinking-water has limitations against the protozoan pathogens, in particular Cryptosporidium [26]. C. parvum is protozoan parasite causes Cryptosporidiosis in humans. Oocysts of C. parvum in $87 \%$ of raw water samples and $27 \%$ of drinking water samples in 15 Canadian regions [25]. Le Chevallier et al. reinforced the present counts of $C$. parvum-cysts which is higher than those of $G$. lamblia in all watersources [25]. Cyclospora cayetanensis is cyst-forming coccidian protozoan that causes a self-limiting diarrhea named cyclosporiasis, with symptoms range from watery, loose stool, weight loss, cramping, fatigue, vomiting, fever and nausea [26].

The maximum score of coliform bacteria are for Proteus and the minimum for Enterobacter. Proteus species causes wound infections, septicemia and pneumonia whereas E. coli produce potentially lethal toxins and causes food poisoning. Moreover, Uro-pathogenic E. coli is responsible for $90 \%$ of urinary tract infections [27]. Enterobacter causes opportunistic infections, where the urinary and respiratory tracts are the sites of infection [28].

Concerning other gram positive bacteria, Acinetobacter haemolyticus causes pneumonia, bacteremia and meningitiz [29], Pseudomonas aeruginosa infects urinary tract, burns, wounds and causes blood infections [9].

Gram positive bacteria, included Bacillus subtilis and Staphylococcus hominis cause diseases in severely immune-compromised patients, Bacillus cereus causes severe nausea, vomiting, and diarrhea, Bacillus anthracis leads to anthrax disease [30], Staphylococcus aureus causes scalded-skin syndrome [31], Streptococcus sanguis causes sub-acute bacterial endocarditis [32] and Aeromonas hydrophila produces aerolysin cytotoxic enterotoxin leads to tissue damage [9].
The studies revealed 5 pathogenic fungal species isolated. The maximum count of fungal-species are for Aspergillus flavus and minimum for Cladosporium cladosporioides. The most common pathogenic species are Aspergillus fumigatus and A. flavus. The latter species produces aflatoxin-toxin that contaminating foods and considers carcinogen leads to allergic disease while A. fumigatus causes allergic disease leads to chronic pulmonary infections [33]. Alternaria alternate causes respiratory infections and asthma in humans with compromised immunity [34]. Hyalo-hyphomycosis that caused by Acremonium includes arthritis, osteomyelitis, peritonitis, endocarditis, pneumonia, cerebritis, and subcutaneous infection [35]. Exophiala jeanselmei causes mycetoma, localized cutaneous infections, subcutaneous cysts, endocarditis, cerebral and disseminated infections, beside phaeohyphomycosis [36]. The highest value of the algae are for Merismopedia tenuissima and minimum for Anabaena sphaerica. Anabaena sphaerica and Microcystis aeruginosa secrete both microcystin-LR and cylindrospermopsin toxins that leading to liver inflammation, pneumonia, dermatitis, kidney damage and tumor growth. Anatoxin-a group ${ }^{3}$-toxin is also secreted by Anabaena and Oscillatoria limnetica, that causes nervous disorders [14]. Concerning standard levels of microorganisms in drinking water, EPA's (Environment Protection Agency) MCLG declared that detection of protozoans, especially Cryptosporidium, is difficult and not technically feasible for routine analysis of human drinking water. The recommendation considered the proper way to control pathogenic protozoans is using an effective water treatment technique, such as reverse osmosis or ozonation.

According to EPA MCL, coliform must be less than one $/ 100 \mathrm{~mL}$. In this concern, the microbiological guidelines and standards for drinking water for E. coli are zero CPU count $/ 100 \mathrm{ml}$ [37]. In this respect, average count $/ 100 \mathrm{~mL}$ of all water sources of the present work revealed considerable higher levels than those of EPA MCL and an apparent risk on Rafha's citizens-health.

The present investigation indicated that water sources of Rafha city are important contributor to transmission of contaminants to consumers. The present work recommends a future-field-application of selected specialized anti-parasites and anti-microbial to control the present resulting contaminators to gain considerable safe levels of drinking water.

\section{Acknowledgment}

The authors would like to acknowledge the approval and the support of this research study by the Deanship of the Scientific Research, Northern Border University, Arar, KSA and thanks to Dean of Faculty of Science and Arts, Rafha The authors want to extend our appreciation to Doaa Abd Allah and Doaa Ibrahim for review of this research

\section{References}

1. Craun GF, Brunkard JM, Yoder JS, Roberts VA, Carpenter J, et al. (2010) Causes of outbreaks associated with drinking water in the United States from 1971 to 2006. Clin Microbiol Rev 23: 507-528.

2. Sánchez-Vega JT, Cabrera-Fuentes HA, Romero-Olmedo AJ, Ortiz-Frías JL, Sokolina F, et al. (2014) Cyclospora cayetanensis: this emerging protozoan pathogen in Mexico. Am J Trop Med Hyg 90: 351-353.

3. Jann-Tay W, Pei-Chen C, Shan-Chwen C, Yih-Ru S, Hui-Ying W, et al. (2014) Antimicrobial susceptibilities of Proteus mirabilis: a longitudinal nationwide study from the Taiwan surveillance of antimicrobial resistance (TSAR) program. BMC infectious diseases 14: 486 .

4. Collee JG, Fraser AG, Marmion BP, Simmonsn A (1996) In: Mackie and McCartney Practical Medical Microbiology (14thedn) Churchill Livingstone.

5. Jeffrey LK (2011) Indicator Organism Assays: Chaos, Confusion and Criteria. 
Citation: Abdel Haleem AA, Hemida SK, Abdellatif MM (2016) Evaluation of Microorganisms of Drinking Water of Rafha City, Northern Borders, Saudi Arabia. J Cytol Histol 7: 417. doi:10.4172/2157-7099.1000417

6. Tilley DO, Arman M, Smolenski A, Cox D, O'Donnell JS, et al. (2013) Glycoprotein Iba and FcyRlla play key roles in platelet activation by the colonizing bacterium, Streptococcus oralis 11: 941-50.

7. Miliotis MD, Bier JW (2003) International Handbook of Foodborne Pathogens. CRC Press 361

8. Mc Clatchey KD (2002) Clinical Laboratory Medicine. Lippincott Williams \& Wilkins.

9. Janda JM, Abbott SL (2003) The genus Aeromonas: taxonomy, pathogenicity, and infection. Clinical Microbiology Reviews 23: 35-73.

10. Person AK, Chudgar SM, Norton BL, Tong BC, Stout JE (2010) Aspergillus niger: an unusual cause of invasive pulmonary aspergillosis. $\mathrm{J}$ Med Microbiol 59: 834-838.

11. Cabañes FJ, Sutton DA, Guarro J (2014) Chrysosporium-Related Fungi and Reptiles: A Fatal Attraction. PLoS Pathog 10.

12. Singh AM, Busse WW (2006) Asthma exacerbations 2: Aetiology. Thorax 61: 809-816.

13. Varkey JB, Perfect JR (2008) Rare and Emerging Fungal Pulmonary Infections Semin Respir Crit Care Med 29: 121-131.

14. (2012) US-EPA Cyanobacteria and Cyanotoxins: Information for Drinking Water Systems. pp: 2-3.

15. SASO Bottled and unbott1ed drinking water (1984) SASO Information Center, Riyadh, Saudi Arabia, pp: 1-8.

16. WHO Guidelines for Drinking Water Quality (1993) V (1): Recommendations (2ndedn) Geneva.

17. Amer A (2007) Effect of Different Types of Pollutants on Bacterio-Zooplankton Interactions in the Nile Water. A thesis submitted of $\mathrm{PhD}$ in science (Zoology), Girls College, Ain Shams Uni.

18. Bakir B, Tanyuksel M, Saylam F, Tanriverdi S, Araz RE (2003) Investigation of Waterborne Parasites in Drinking Water Sources of Ankara, Turkey. The Journal of Microbiology $\mathrm{p}:$ 148-151.

19. Sabahi EA, Rahim AS, Zuhairi WWY, Alshaebi F, Nozaily FA (2009) Assessment of Groundwater and Surface Water Pollution at Mitm Area, Ibb City, Yemen. American Journal of Applied Sciences 6: 772-783.

20. Kawther FA (2007) Antimicrobial Activity of Essential Oils of Some Medicinal Plants from Arab Saudi. Saudi Journal of Biological Sciences 14: 53-60.

21. Domsch KH, Gams W, Anderson T (2007) Compendium of soil fungi. (2ndedn) IHW Veriag Eching pp: 1-672.
22. Prescott GW (1954) How to know the freshwater algae. Brown Co. Dubuque, lowa p: 228.

23. Al-Turki Al (2009) Evaluation of well water quality in Hael region of centra of Saudi Arabia. Thirteenth International Water Technology Conference IWTC Hurghada, Egypt.

24. WHO Diarrhoeal disease (2009) Geneva.

25. Le Chevallier MW, Norton WD, Lee RG (1991) Giardia and Cryptosporidium spp in filtered drinking water supplies. Appl Environ Microbiol 57: 2617-2621.

26. WHO Guidelines for Drinking-water Quality (2011) (4thedn) WHO Library Cataloguing in Publication Data.

27. Todar K (2007) Pathogenic E. coli Online Textbook of Bacteriology. University of Wisconsin-Madison Department of Bacteriology.

28. Jesumirhewe C, Umebuani DA, Ogunlowo PO (2014) Multidrug resistance of Enterobacter aerogenes isolated from bovine animals in okada, edo. Nova Journal of Medical and Biological Sciences 2: 1-6.

29. Debarry J, Hanuszkiewicz A, Stein K, Holst O, Heine H (2009) The allergyprotective properties of Acinetobacter Iwoffii F78 are imparted by its lipopolysaccharide. Allergy 65: 690-697.

30. Schneider KR, Parish ME, Goodrich RM, Cookingham T (2004) Preventing foodborne illness: Bacillus cereus and Bacillus anthracis. FSHN04-05 (Food science and human nutrition) University of Florida.

31. Fridkin SK, Hageman JC, Morrison M, Sanza LT, Como-Sabetti K, et al. (2005) Methicillin-resistant Staphylococcus aureus disease in three communities. The New England Journal of Medicine 352: 1436.

32. Alves JM, Kitten T, Brown A, Chen Z, Ozaki LS, et al. (2007) Genome of the opportunistic pathogen Streptococcus sanguinis. J Bacteriol 189: 3166-3175.

33. Warris A, Klaassen CHW, Meis JFGM, de Ruiter MT, de Valk HA, et al. (2003) Molecular epidemiology of Aspergillus fumigatus isolates recovered from water, air, and patients shows two clusters of genetically distinct strains. Journal of Clinical Microbiology 41: 4101-6.

34. Lederman MM (1987) Alternaria Infection in a Patient with Acquired Immunodeficiency Syndrome: Case Report and Review of Invasive Alternaria Infections. Reviews of Infectious Diseases 9: 799-803.

35. Fincher RM, Fisher JF, Lovell RD, Newman CL, Espinel A, et al. (1991) Infection due to the fungus Acremonium. Medicine 70: 398-409.

36. Vitale RG, De Hoog GS (2002) Molecular diversity, new species and antifungal susceptibilities in the Exophiala spinifera clade. Med Mycol 40: 545-556.

37. Natural Mineral Water, Spring Water and Bottled Drinking Water (Wales) (Amendment) Regulations (2011) (W.S.I. No. 400 (W.57) 